\title{
The influence of ammonia, biogenic amines and $\gamma$-aminobutyric acid on grass silage intake in sheep
}

\author{
BY M. VAN OS*, M. JAILLER AND J. P. DULPHY $†$ \\ INRA, CRZV de Theix, Station de Recherches sur la Nutrition des Herbivores, \\ 63122 Saint Genès-Champanelle, France
}

(Received 2 May 1995 - Revised 20 November 1995-Accepted 5 December 1995)

\begin{abstract}
We investigated whether biogenic amines alone, or a combination of $\mathrm{NH}_{3}$, amines and $\gamma$-aminobutyric acid (GABA) influenced grass-silage intake, intake behaviour and rumen liquid content in sheep. Three diets were studied: a grass silage preserved with formic acid (4 litres/tonne) (FAS), FAS with $4.9 \mathrm{~g}$ amines/kg DM added (FAS $+\mathbf{A}$ ), and FAS supplemented with a combination of N-components at the following concentrations: $2.7 \mathrm{~g}$ amines, $3.0 \mathrm{~g} \mathrm{NH}_{3}$ and $5.0 \mathrm{~g} \mathrm{GABA} / \mathrm{kg} \mathrm{DM}(\mathrm{FAS}+\mathrm{C})$. The diets were offered ad libitum, once daily to six rumen-cannulated Texel wethers in a crossover design. Daily DM intake (DMI; $g$ DM/d) tended to be influenced by diet $(P=0.08)$. The DMI of FAS + A was similar to that of FAS alone, whereas that of FAS $+C$ tended to be higher. The mean rate of ingestion (g DM/min) over all feeding bouts tended to be the lowest for FAS + A $(P=0 \cdot 06)$. No differences were found among the diets concerning intake behaviour during the principal meal. Average intake rate of the small meals tended to be the lowest for FAS $+\mathrm{A}(P=0.06)$. Although rumen $\mathrm{NH}_{3}$ concentration was higher $(P<0.05)$ after the principal meal, rumen pH, osmolality, rumen pool size and liquid content were not significantly altered by adding amines or the mixture of $N$-components to FAS. We conclude that biogenic amines or $\mathrm{N}$-containing products of protein fermentation in concentrations normally found in poor-quality silages do not reduce the intake of well-preserved formic acid-treated silage. A direct effect on chemostatic regulation of intake was not observed, but a slight negative effect on silage palatability cannot be excluded.
\end{abstract}

Grass silage: Voluntary intake: Amines: Sheep

Ensiling grass may alter the nutritional value of the original herbage considerably. Soluble carbohydrates are converted to the preserving organic acids (McDonald et al. 1991), and a significant part of the plant protein is degraded into non-protein N (NPN) comprising peptides, amino acids (Heron et al. 1986), amines and $\mathrm{NH}_{3}$ (Voss, 1967). The generally observed lower intake of grass silage when compared with that of hay prepared from the same forage, or the lower intake of silages of inferior quality, may be attributed to the fermentation products in them (Chiofalo et al. 1992; Thiago et al. 1992). Presumably, they reduce intake by lowering silage palatability or by evoking signals of satiation from intakeregulating mechanisms located in the rumen or from intermediary metabolism (Gill et al. 1987; Baile \& Della-Fera, 1988). Among the fermentation products, those of protein degradation, especially biogenic amines, are suggested to lower silage intake (BuchananSmith \& Phillip, 1986). In a previous experiment we observed that addition of $3 \mathrm{~g} / \mathrm{kg} \mathrm{DM}$ of a mixture of four biogenic amines, commonly present in a poorly-preserved silage, to a well-preserved grass silage tended to depress intake by lowering palatability (Van Os et al. $1995 a$ ). Moreover the rumen fluid volume tended to be higher on addition of this relatively

* Present address: DLO-Institute for Animal Science and Health (ID-DLO), PO Box 65, 8200 AB Lelystad, The Netherlands.

$\dagger$ For correspondence and reprints. 
low quantity of amines to the experimental diet. However, the results did not allow us to judge whether biogenic amines acted on chemostatic intake regulation at the ruminal or the metabolic level.

The aim of the present experiment was to confirm the negative influence of biogenic amines on silage intake and to establish their interference with chemostatic intake regulation by adding about $5 \mathrm{~g}$ biogenic amines/ $\mathrm{kg} \mathrm{DM}$ to a good-quality silage. Additionally, the effect of a combination of NPN components $\left(\mathrm{NH}_{3}\right.$, biogenic amines and $\gamma$-amino butyric acid (GABA)) on silage intake was studied. GABA was included in the combination of NPN tested because of its presence in significant amounts in naturally fermented silages (Ohshima et al. 1979), the fact that GABA is found to be a neurotransmitter in the central nervous system acting on feed intake control (Seoane et al. 1984) and the fact that GABA depressed intake in sheep when infused into the rumen or intravenously (Buchanan-Smith, 1982).

\section{MATERIALS AND METHODS}

\section{Dietary treatments and feeding}

The basal diet consisted of a formic acid-treated (4 litres/tonne fresh material) grass silage prepared from a first cut from a cocksfoot (Dactylis glomerata) meadow. After a $24 \mathrm{~h}$ wilt, the grass was harvested with a precision-chop forage harvester and ensiled in a clamp silo. In the experiment, three diets were studied: the formic acid silage alone (FAS), FAS supplemented with $4.9 \mathrm{~g}$ biogenic amines/kg DM (FAS + A) and FAS supplemented with a combination of NPN components consisting of a total of $2.7 \mathrm{~g}$ biogenic amines $/ \mathrm{kg} \mathrm{DM}$, $\mathrm{NH}_{3}$ and GABA (FAS + C). Amounts of the individual amines added were fixed for $\mathrm{FAS}+\mathrm{A}$ to achieve an amine content of this silage that was higher than that tested in a previous similar study by Van Os et al. (1995a). For FAS $+\mathrm{C}$ the same amounts of amines and $\mathrm{NH}_{3}$ were added as by Van Os et al. (1995a) while the amount of GABA was determined from concentrations commonly found in poorly-preserved silages (Ohshima $e t$ al. 1979). Amounts of each NPN component added to FAS to obtain the diets FAS + A and $\mathrm{FAS}+\mathrm{C}$ are given in Table 1 . The amines cadaverine, histamine, putrescine and tyramine, in hydrochloric form, and GABA were purchased from Sigma Chimie, St Quentin Fallavier, France, and the $\mathrm{NH}_{3}$ solution (Normapur ${ }^{\mathrm{TM}} ; 200 \mathrm{ml} / \mathrm{l}$ ) was purchased from Prolabo, Paris, France. All quantities of amines given in this study represent the free bases and not the hydrochlorides. The amines and GABA necessary to supplement $50 \mathrm{~kg}$ fresh material of FAS to obtain either FAS + A or FAS + C were dissolved in 1.5 litres water before being mixed with FAS. The $\mathrm{NH}_{3}$ solution was added undiluted. Additionally, the same volume of water without amines or NPN components was mixed with FAS, so that the texture and DM content of the control FAS would not differ from the other dietary treatments. Every $2 \mathrm{~d}$, portions of $50 \mathrm{~kg}$ (fresh material) of the three diets were prepared and stored at $+4^{\circ}$.

After the refusals of the previous day were collected, the diets were offered ad libitum to the sheep in amounts sufficient to ensure refusal of at least $10 \%$, once daily at 09.00 hours.

\section{Animals and experimental design}

Six 6-year-old Texel wethers (average live weight $69 \mathrm{~kg}$ ) were used, each fitted with a permanent rumen cannula ( $75 \mathrm{~mm}$ in diameter). Throughout the experiment the animals were kept in an experimental room, which was lit for $11 \mathrm{~h} / \mathrm{d}$. During adaptation periods they were housed in individual pens with sawdust for bedding. During experimentation they were kept in metabolism cages, in which they were placed $5 \mathrm{~d}$ before. During the experiment the animals had free access to water and salt blocks. 
Table 1. Amounts of individual non-protein nitrogen components added $(\mathrm{g} / \mathrm{kg} \mathrm{DM})$ to formic acid-preserved grass silage $(F A S)$ to obtain the dietary treatments $F A S+A$ and $F A S+C$

\begin{tabular}{lcc}
\hline N source & FAS $+\mathrm{A}$ & FAS $+\mathrm{C}$ \\
\hline Cadaverine & $1 \cdot 1$ & $\mathbf{0 . 6}$ \\
Histamine & $\mathbf{0 . 8}$ & $\mathbf{0 \cdot 5}$ \\
Putrescine & $1 \cdot 2$ & $0 \cdot 7$ \\
Tyramine & $1 \cdot 8$ & $1 \cdot 0$ \\
& - -Aminobutyric acid & $5 \cdot 0$ \\
Ammonia & - & $3 \cdot 0$ \\
\hline
\end{tabular}

The sheep were randomly allocated, two by two, to each sequence of three dietary treatments in a crossover design with three periods. Each period in the crossover lasted for 4 weeks, and consisted of a 2-week period for adaptation to the diet and a further 2-week period in which intake behaviour was recorded and measurements on rumen fill and its characteristics were carried out.

\section{Measurements and sampling}

During periods of measurement, samples of the diets were collected daily and analysed for DM content. In each period, pooled samples of each diet were stored at $-20^{\circ}$ until they were analysed for fermentation products.

The DM intake (DMI) was determined daily throughout the experiment, and was calculated as the difference between the amount of DM offered and the amount of DM refused. Intake behaviour was monitored during five consecutive days by continuously weighed mangers, and jaw movements of the sheep were recorded simultaneously by a foam-filled balloon placed submandibularly. Air-pressure signals from distortion of the balloon were converted into electrical signals by a pressure transducer and were recorded by a microcomputer. In an earlier study we described in detail the procedures of recording intake behaviour, fitting the intake curve of the principal meal (first meal after feeding), and collecting samples of rumen fluid and rumen emptyings (Van Os et al. 1995a).

During two consecutive days, simultaneously with intake behaviour recordings, rumen fluid was withdrawn from the ventral region by peristaltic pump. From 08.30 to 12.00 hours sampling was carried out continuously $(60 \mathrm{ml} / \mathrm{h})$; samples $(30 \mathrm{ml})$ were collected every $30 \mathrm{~min}$ and additionally at $14.00,15.00$ and 16.00 hours. At the aspiration site the fluid was filtered through a nylon bag with a pore size of $0.041 \mathrm{~mm}$.

Cr-EDTA was used as a marker of the liquid phase to determine rumen fluid volume and the turnover rate (Binnerts et al. 1968). On the first day of rumen fluid sampling a single dose of $300 \mathrm{ml}$ was introduced into the rumen through the rumen cannula at 07.00 hours. Previously, a fluid sample $(100 \mathrm{ml})$ was taken to be analysed for background Cr levels. All samples collected were analysed for $\mathrm{Cr}$ concentration. The samples collected at 09.00 hours just before feeding and at $09.30,10.00,10.30,14.00$ and 16.00 hours were additionally analysed for $\mathrm{NH}_{3}-\mathrm{N}$ concentration, $\mathrm{pH}$ and osmolality.

Total rumen fill before ( 08.30 hours) and after ( 10.30 hours) the principal meal was determined by manually emptying the rumen at given times at $3 \mathrm{~d}$ intervals. The complete collection of digesta was weighed, briefly mixed (manually) and sampled for DM content and amine extraction. Rumen-fluid samples were also prepared to determine $\mathrm{pH}, \mathrm{NH}_{3}-\mathrm{N}$ concentration and osmolality. Additional measurements made, and those relating to the rumen liquid content, were ad libitum water intake, which was measured during the $5 \mathrm{~d}$ of 
intake behaviour recordings (including rumen fluid sampling days), and saliva production during mastication. To measure salivation, a series of ingestive mastication boli $(n 10)$ was collected when expelled from the cardia into the reticulum of the emptied rumen $(08.30$ hours). These boli were weighed and analysed for DM content. Under the assumption that DM content of the bolus reflected the silage DM, the saliva content was calculated as the difference between total weight and DM content plus the moisture content of the silage. However, it must be noted that salivation rate during intake differs from that during rumination or rest (Church, 1976). Therefore, the rate measured in this study cannot be extrapolated beyond the time point it was measured.

To determine a possible overall effect of amines in the diet on body temperature, this was measured rectally with a clinical thermometer at 08.30 and 17.00 hours on the days that intake behaviour was recorded.

\section{Chemical analysis}

The DM content of silage, refusals, rumen content and mastication boli was determined by oven drying at $80^{\circ}$ for $48 \mathrm{~h}$. Silage DM content was corrected for the loss of volatile components occurring during oven drying according to the method of Dulphy et al. (1975). Fermentation characteristics of the silages $(\mathrm{pH}$, volatile fatty acids (VFA), alcohols, lactic acid, $\mathrm{NH}_{3}-\mathrm{N}$, and soluble $\mathrm{N}$ ) were determined in the juice pressed from the silages, while total $\mathrm{N}$ and amine concentrations were determined in the fresh material. Full details of methods used for analysing silage composition, rumen fluid $\mathrm{NH}_{3}-\mathrm{N}$ and osmolality are described by Van Os et al. (1995a). The Cr concentration in the rumen fluid samples was determined in the supernatant fraction, after centrifugation $(20 \mathrm{~min}, 40000 \mathrm{~g})$, by atomic absorption spectrometry (Perkin-Elmer 23800, Bois d'Arcy, France) at the wavelength of $357.9 \mathrm{~nm}$. $\alpha$-Aminobutyric acid (AABA) and GABA were extracted from the silage using the same extraction method as used for the biogenic amines (Van Os et al. 1995a). They were determined in the supernatant fraction by ion-exchange chromatography (Pharmacia LKB Biochrom Ltd, Roosendaal, The Netherlands; Aminoacid Analyzer alpha plus 4151).

\section{Calculations}

Liquid passage. The volume of the rumen liquid and its turnover rate were determined by fitting the model $\mathrm{C}_{t}=\mathrm{C}_{0} \times \mathrm{e}^{-k t}$ to the data of the $\mathrm{Cr}$-concentration curve in the rumen fluid over the two sampling days. In this model, $\mathrm{C}_{t}$ and $\mathrm{C}_{0}$ are the marker concentrations at time $t$ and time 0 respectively; $k$ is the fractional turnover rate constant (\% per $\mathrm{h}$ ), and $t$ is the time (h) after marker introduction. The parameter $k$ and the rumen liquid volume at $t_{0}$ were estimated using the Marquardt method of the non-linear (NLIN) procedure of the SAS Institute Inc. (1987).

\section{Statistical analysis}

Data were subjected to ANOVA using the general linear models procedure of the SAS Institute Inc. (1987). Because no carry-over effects were observed between periods, effects of dietary treatment ( $2 \mathrm{df})$, animals $(5 \mathrm{df})$ and period $(2 \mathrm{df})$ were tested. Differences between diets were compared using Student's $t$ test.

\section{RESULTS}

Diet composition

Fermentation quality of the basic silage (FAS) was considered good according to the classification of Dulphy \& Demarquilly (1981), as indicated by low $\mathrm{pH}$, low acetic and butyric acid contents and low proportions of total $N$ content present as soluble $N\left(N_{\text {sol }}\right)$ and 
Table 2. Chemical composition and fermentation characteristics $(\mathrm{g} / \mathrm{kg} D M)$ of the dietary treatments: the formic acid preserved grass silage $(F A S), F A S$ after amine addition $(F A S+A)$ and after addition of a combination of nitrogenous components $(F A S+C)$

\begin{tabular}{|c|c|c|c|}
\hline & FAS & $\mathrm{FAS}+\mathrm{A}$ & $\mathrm{FAS}+\mathrm{C}$ \\
\hline DM (g/kg fresh weight) & 231 & 227 & 229 \\
\hline $\mathrm{pH}$ & $4 \cdot 0$ & 4.0 & $4 \cdot 2$ \\
\hline Crude protein $(\mathrm{N} \times 6.25)$ & 165 & 169 & 184 \\
\hline $\mathrm{NH}_{3}-\mathrm{N}(\%$ total $\mathrm{N})$ & $8 \cdot 1$ & $8 \cdot 0$ & $15 \cdot 4$ \\
\hline Soluble N (\% total $\mathrm{N})$ & $50 \cdot 4$ & $52 \cdot 2$ & $57 \cdot 1$ \\
\hline Lactic acid & $82 \cdot 6$ & $75 \cdot 1$ & $72 \cdot 8$ \\
\hline VFA & $22 \cdot 3$ & $19 \cdot 8$ & $22 \cdot 6$ \\
\hline Acetic acid & $19 \cdot 4$ & 17.6 & $19 \cdot 8$ \\
\hline Propionic acid & $1 \cdot 2$ & 0.8 & $1 \cdot 2$ \\
\hline Butyric acid & 1.7 & 1.4 & 1.6 \\
\hline Alcohols & $3 \cdot 7$ & 3.6 & $3 \cdot 3$ \\
\hline Amines & $2 \cdot 4$ & $7 \cdot 4$ & $5 \cdot 1$ \\
\hline Cadaverine & $0-4$ & 1.5 & $1 \cdot 1$ \\
\hline Histamine & $0 \cdot 4$ & $1 \cdot 1$ & 0.7 \\
\hline Putrescine & $0-4$ & 1.5 & $1 \cdot 1$ \\
\hline Tyramine & $1 \cdot 2$ & $3 \cdot 3$ & $2 \cdot 2$ \\
\hline$\gamma$-Aminobutyric acid & $2 \cdot 0$ & $2 \cdot 1$ & $6 \cdot 4$ \\
\hline$\alpha$-Aminobutyric acid & 0.1 & $0 \cdot 2$ & $0 \cdot 1$ \\
\hline
\end{tabular}

VFA, volatile fatty acids.

$\mathrm{NH}_{3}-\mathrm{N}$ (Table 2). Addition of the different $\mathrm{N}$-components to FAS resulted in the desired increase of biogenic amine content in the FAS + A diet, and the concentrations of different NPN components $\left(\mathrm{NH}_{3}-\mathrm{N}\right.$, biogenic amines and GABA) in the FAS $+\mathrm{C}$ diet. Adding amines did not significantly alter $\mathrm{pH}$ and crude protein (CP) content in $\mathrm{FAS}+\mathrm{A}$ when compared with FAS. Adding the mixture of $\mathrm{N}$-components, however, slightly increased $\mathrm{CP}$ content and the proportion of $\mathrm{N}_{\mathrm{sol}}$ of $\mathrm{FAS}+\mathrm{C}$, and its $\mathrm{pH}$ value as a result of the buffering properties of the added $\mathrm{N}$-components.

\section{Intake and intake behaviour}

Daily DMI and means of the variables of intake behaviour are given in Table 3. Daily DMI were similar for FAS and FAS $+\mathrm{A}$, but tended to be higher for FAS $+\mathrm{C}(P=0.08)$. The average rate of intake of the daily ration also tended to be affected by dietary treatment $(P=0.06)$, and was lowest for FAS $+\mathrm{A}$.

Neither addition of amines alone nor addition of the mixture of NPN components significantly altered the intake variables at the principal meal. The amount eaten averaged 316 (SE 13) g DM. So, tendencies of dietary treatment to affect intake rate of the daily ration, originated mainly from influences on the average intake rate of the subsequent small meals. This tended to be lowest for FAS + A and highest for FAS + C. The number of small meals, however, was not affected by type of diet. Furthermore, neither amines nor the combination of NPN components appeared to influence rumination behaviour or mastication efficiency, i.e. the amount of DM chewed per min of total mastication.

\section{Rumen fermentation}

The average $\mathrm{NH}_{3}$ concentration in the rumen fluid before feeding was 146 (SE 11$) \mathrm{mg} / 1$ and did not differ significantly between treatments (Fig. 1(a)). After the sheep were fed, rumen $\mathrm{NH}_{3}$ increased for all diets. This increase was largest for FAS $+\mathrm{C}$, attaining the 
Table 3. DM intake (DMI), intake rates and duration of different feed intake activities of sheep offered ad libitum grass silage preserved with formic acid (FAS), FAS supplemented with amines $(F A S+A)$ and $F A S$ with a combination of nitrogenous components $(F A S+C)^{*}$

(Mean values for six sheep)

\begin{tabular}{|c|c|c|c|c|c|}
\hline & FAS & $\mathbf{F A S}+\mathbf{A}$ & $\mathrm{FAS}+\mathrm{C}$ & $\begin{array}{c}\text { Significance } \dagger \\
\text { of the } \\
\text { diet effect }\end{array}$ & $\begin{array}{c}\text { Pooled } \\
\text { SED }\end{array}$ \\
\hline Daily DMI (g) & 1187 & 1293 & 1327 & $0-08$ & 62 \\
\hline Intake rate $(\mathrm{g} \mathrm{DM} / \mathrm{min})$ & $3 \cdot 8$ & $3 \cdot 6$ & $4 \cdot 2$ & 0.06 & 0.22 \\
\hline \multicolumn{6}{|l|}{ Principal meal } \\
\hline Intake $(\mathrm{g})$ & 304 & 316 & 330 & NS & 25 \\
\hline Duration (min) & 48 & 53 & 48 & NS & 4 \\
\hline Intake rate (g DM $/ \mathrm{min})$ & 6.5 & $5 \cdot 9$ & 6.9 & NS & 0.56 \\
\hline Initial rate & $12 \cdot 0$ & $11 \cdot 0$ & $11 \cdot 9$ & NS & $1 \cdot 10$ \\
\hline Final rate & $3 \cdot 6$ & $3 \cdot 2$ & $4 \cdot 0$ & NS & $0 \cdot 56$ \\
\hline \multicolumn{6}{|l|}{ Small meals } \\
\hline No. & $11 \cdot 3$ & $10 \cdot 2$ & $11 \cdot 2$ & NS & 0.63 \\
\hline Intake rate (g DM/min) & $3 \cdot 4$ & $3 \cdot 1$ & $3 \cdot 8$ & 0.07 & $0 \cdot 17$ \\
\hline \multicolumn{6}{|l|}{ Rumination } \\
\hline Duration (min/kg DMI) & 310 & 336 & 320 & NS & 21 \\
\hline Lag time + & 168 & 145 & 152 & NS & 20 \\
\hline \multicolumn{6}{|l|}{ Mastication } \\
\hline Duration (min/kg DMI) & 578 & 620 & 565 & NS & 27 \\
\hline Efficiency (g DM/min) & 1.74 & $1 \cdot 64$ & 1.78 & NS & 0.08 \\
\hline
\end{tabular}

SED, standard error of the difference between means $(8 \mathrm{df})$.

* For details of diets and procedures, see Table 2 and pp. 348-350.

$\dagger$ For tendencies $(0.05<P<0 \cdot 10)$ probabilities are given.

† Start of first rumination after silage distribution (min).

concentration of $478 \mathrm{mg} \mathrm{NH} / 1$ at 90 min after feeding. This $\mathrm{NH}_{3}$ concentration was significantly higher $(P<0.05)$ than those measured for FAS and FAS + A at 90 min after feeding. At further sampling times, rumen $\mathrm{NH}_{3}$ decreased slowly for all diets, but with FAS $+\mathrm{C}$, the silage with the greatest NPN fraction, rumen $\mathrm{NH}_{3}$ always remained slightly higher than in FAS and FAS + A.

Rumen fluid pH (Fig. 1(b)) before feeding was significantly higher with FAS + C. After feeding, rumen $\mathrm{pH}$ decreased and remained relatively constant with a mean value of 6.46 (SE 0.06) for the remainder of the sampling period without significant differences between diets.

Time courses of rumen fluid osmolality (Fig. 1(c)) were similar for the three dietary treatments. Before feeding, osmolality was low and averaged 261 (SE 5) mosmol/1. After feeding rumen osmolality increased to an average of 325 (SE 6) mosmol/1 for all three diets, and then decreased during the sampling period.

\section{Rumen fill and characteristics of rumen contents}

Details regarding the contents of the reticulo-rumen obtained after manual emptyings before ( 08.30 hours) and after the principal meal ( 10.30 hours) are presented in Table 4 . At both times the diets did not apparently influence the total rumen pool size, nor its DM or liquid content.

The rumen fluid was also analysed for $\mathrm{pH}, \mathrm{NH}_{3}$ content and osmolality at both times that the rumen was emptied. Results (not shown) agreed with those measured for 

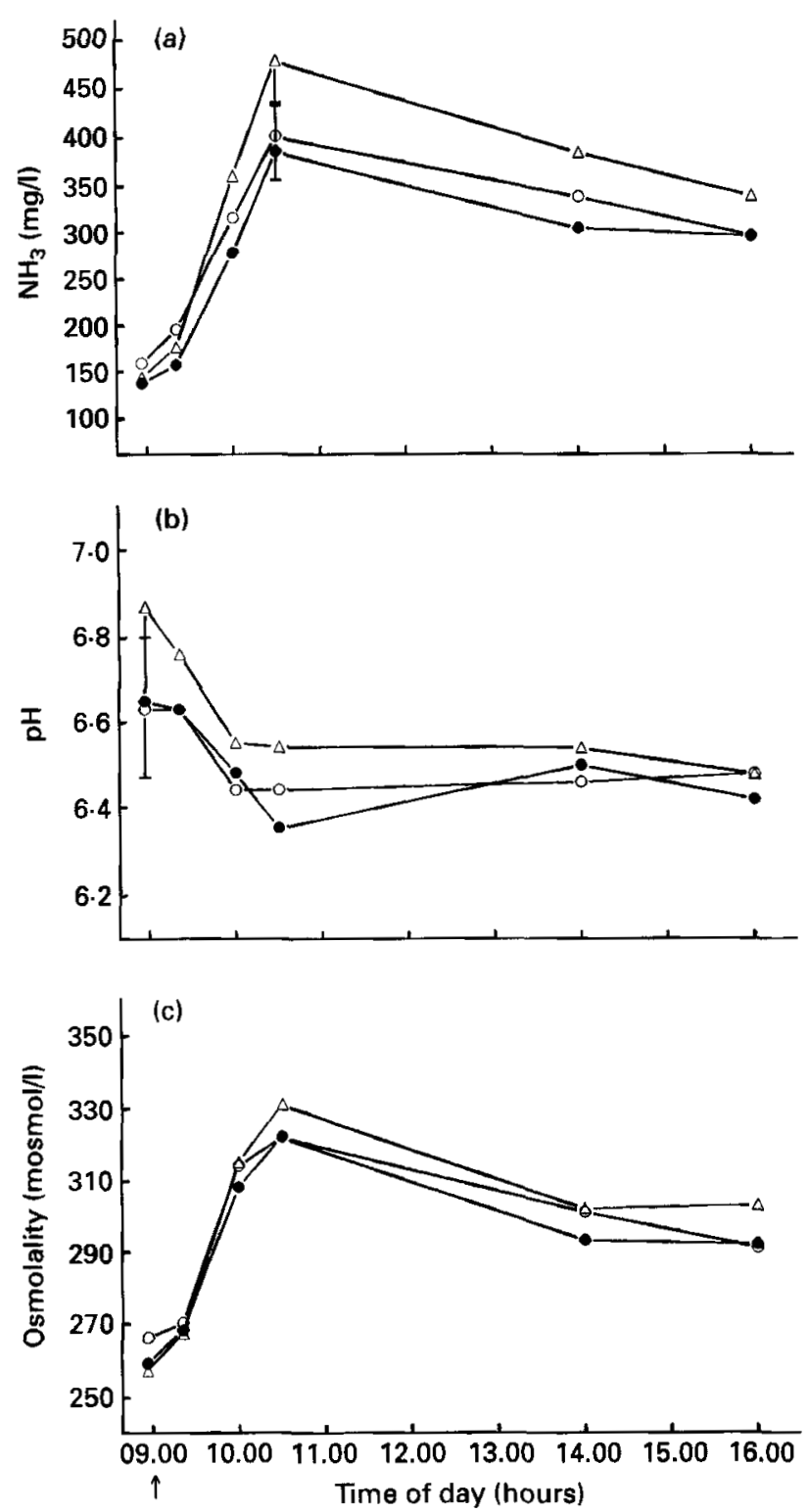

Fig. 1. Diurnal changes in (a) ammonia concentration, (b) $\mathrm{pH}$ and (c) osmolality in rumen fluid from sheep offered ad libitum grass silage preserved with formic acid (FAS, O), FAS after addition of amines (FAS $+A$, $)$ or a combination of nitrogenous components $(\mathrm{FAS}+\mathrm{C}, \triangle) .(\uparrow)$, Point of silage distribution to the sheep.

determining the patterns of $\mathrm{pH}, \mathrm{NH}_{3}$ and osmolality in the rumen fluid. With all dietary treatments, no biogenic amines were found in the rumen content sampled at 08.30 hours, and only traces were found at 10.30 hours $(<35 \mathrm{mg} / \mathrm{kg}$ DM for putrescine and $<19 \mathrm{mg} / \mathrm{kg}$ DM for other biogenic amines).

No diet influences were found on rumen liquid volume and turnover rate, estimated by the Cr-EDTA marker (Table 5). The rumen volume before feeding estimated with the Cr- 
Table 4. Content of the reticulo-rumen before (08.30 hours) and after (10.30 hours) the principal meal*, in sheep offered ad libitum grass silage preserved with formic acid $(F A S)$, $F A S$ supplemented with amines $(F A S+A)$ and $F A S$ with a combination of nitrogenous components $(F A S+C) \dagger$

(Mean values for six sheep)

\begin{tabular}{|c|c|c|c|c|c|}
\hline & FAS & $\mathrm{FAS}+\mathrm{A}$ & $\mathrm{FAS}+\mathrm{C}$ & $\begin{array}{l}\text { Significance } \\
\text { of the } \\
\text { diet effect }\end{array}$ & $\begin{array}{l}\text { Pooled } \\
\text { SED }\end{array}$ \\
\hline \multicolumn{6}{|l|}{08.30 hours } \\
\hline Wet wt $(\mathrm{kg})$ & $9 \cdot 0$ & $9 \cdot 6$ & 8.8 & NS & 0.41 \\
\hline $\mathrm{DM}(\mathrm{g} / \mathrm{kg})$ & 98 & 101 & 91 & NS & 3.9 \\
\hline Fluid (litres) & $8 \cdot 1$ & 8.6 & $8 \cdot 0$ & NS & 0.35 \\
\hline \multicolumn{6}{|l|}{10.30 hours } \\
\hline Wet wt (kg) & $10 \cdot 5$ & $10 \cdot 7$ & $10 \cdot 6$ & NS & $0 \cdot 41$ \\
\hline $\mathrm{DM}(\mathrm{g} / \mathrm{kg})$ & 112 & 109 & 110 & NS & $4 \cdot 6$ \\
\hline Fluid (litres) & $9 \cdot 3$ & 9.5 & $9 \cdot 4$ & NS & 0.34 \\
\hline
\end{tabular}

SED, standard error of the difference between means $(8 \mathrm{df})$.

* First meal after feeding.

$\dagger$ For details of diets and procedures, see Table 2 and pp. 348-350.

Table 5. Rumen volume (litres) estimated by $C r$-EDTA marker and rumen fluid turnover rate $(\%$ per $h)$ in sheep offered ad libitum grass silage preserved with formic acid (FAS), FAS supplemented with amines $(F A S+A)$ and $F A S$ with a combination of nitrogenous components $(F A S+C)^{*}$

\begin{tabular}{llcccc}
\hline & FAS & FAS +A & FAS +C & $\begin{array}{c}\text { Significance } \\
\text { of the } \\
\text { diet effect }\end{array}$ & $\begin{array}{c}\text { Pooled } \\
\text { SED }\end{array}$ \\
\hline $\begin{array}{l}\text { Rumen volume (litres) } \\
\text { Turnover rate of the liquid phase } \\
(\% \text { per } h)\end{array}$ & 9.7 & 9.8 & $10 \cdot 1$ & NS & 0.70 \\
\hline
\end{tabular}

SED, standard error of the difference between means $(8 \mathrm{df})$.

* For details of diets and procedures, see Table 2 and pp. $348-350$.

$\dagger$ Inclusion of daily DM intake as covariable in the model for ANOVA.

EDTA marker, however, was a little higher than that calculated from the characteristics of the rumen content determined by manually emptying the rumen at 08.30 hours (Table 4 ). A significantly $(P<0.05)$ higher silage DMI for FAS $+\mathrm{C}$ during days when rumen fluid was sampled, resulted in a significantly higher liquid turnover rate with FAS + C. Including DMI as a covariate in the model for ANOVA on data of liquid turnover rate eliminated the diet influence related to DMI (Table 5).

With these low DM silages, water intake was very low (150 (SE 25) $\mathrm{ml} / \mathrm{d}$ ), and was not affected by dietary treatment. Furthermore, diet did not seem to influence saliva production during ingestive mastication at the beginning of the first meal, which averaged for all diets 850 (SE 1.4) $\mathrm{g} / \mathrm{kg}$ fresh silage ingested.

Finally, adding biogenic amines or a combination of N-components to FAS did not significantly affect the normal body temperature of the sheep, which averaged $38 \cdot 8$ (SE $0 \cdot 14)^{\circ}$ for both morning and evening measurements on all diets. 


\section{DISCUSSION}

\section{Silages}

The quantities of tyramine, histamine, putrescine and cadaverine in FAS + A were similar to quantities detected in medium-to-poorly preserved silages that led to significantly lower intakes than a good quality silage (Tveit et al. 1992; Van Os et al. 1995a). The concentration of the NPN fraction in FAS +C was similar to that seen in lowfermentation-quality silages, namely with high $\mathrm{NH}_{3}$ content and relatively high concentrations of biogenic amines (Tveit et al. 1992; Van Os et al. 1995a) and GABA (Ohshima et al. 1979).

\section{Intake and intake behaviour}

The tendency for biogenic amines to reduce silage DMI observed by Van Os et al. (1995a) was not observed in the present study, even though higher amounts of amines were added than in the previous experiment. Regression analysis of the relationship between levels of fermentation products in silage and silage intake has shown that silage intake may be negatively correlated with the combination of $\mathrm{NH}_{3}$ and amines in the silage when the total concentration of both exceeds $1.6 \mathrm{~g} / \mathrm{kg} \mathrm{DM}$ (Miettinen et al. 1991). However, Van Os et al. (1995a) concluded that $\mathrm{NH}_{3}$ per se was not an intake depressor and, therefore, interactive effects between $\mathrm{NH}_{3}$ and other $\mathrm{N}$-containing fermentation products may be responsible for the observed lower intake of poorly preserved silages. The results of the present study did not support this hypothesis. On the contrary, DMI of FAS +C tended to be even higher than that of FAS.

It must be noted that DMI of FAS in the present study was lower than that of the control silage preserved with formic acid in the study of Van Os et al. (1995a) (50 v. $65 \mathrm{~g} / \mathrm{kg}$ metabolic weight $\left(\mathrm{W}^{0 \cdot 75}\right)$ ). This could be attributed, possibly, to a lower digestion rate or a higher overall content of fermentation products, especially that of lactic acid (Morgan \& L'Estrange, 1976), which was $21 \mathrm{~g} / \mathrm{kg} \mathrm{DM}$ in the study of Van Os et al. (1995a) $v .83 \mathrm{~g} / \mathrm{kg}$ DM in the present study. Possibly, the slight negative effects of the biogenic amines on DMI observed by Van Os et al. (1995a) were hidden by this low intake. On the other hand, DMI of FAS in the present study was not lower than that of the same type of silages used by Dulphy et al. (1984), and it was within the range of values predicted using equations based on silage $\mathrm{pH}$ and $\mathrm{NH}_{3}$ content or $\mathrm{pH}$ and lactic acid (Wilkins et al. 1971). Moreover, daily DMI of FAS covered largely the daily energy and protein requirements of the sheep for maintenance (Andrieu et al. 1989). Silage intake appears to be controlled mainly by oropharyngeal factors (taste, smell) and chemostatic regulation (satiation) and not by rumen fill (Gill et al. 1987). The similarity between the dietary treatments in the amount eaten and the period of time spent eating during the principal meal indicated that with FAS $+\mathrm{A}$ and FAS $+C$ the state of satiation was reached at the same time as that for the control diet FAS. Similar intake rates at the very beginning of the principal meal, when food intake cannot be inhibited by satiation, as well as during the principal meal, suggested that neither biogenic amines in FAS + A nor the combination of NPN-components in FAS + C lowered palatability of the silage. This did not agree with the results of Van Os et al. (1995a) which showed a slight negative influence of lower quantities of biogenic amines on palatability during both the principal meal and the small meals. This difference in extent of amines affecting palatability is possibly due to the higher overall content of fermentation products of FAS in the present study, or to the sheep getting accustomed to the taste of amines. The latter could be possible, because four of the six sheep that were also used in the previous study of Van Os et al. (1995a) showed, in the present study, slightly higher DMI and intake rates during the principal meal than the new animals. Nevertheless, the tendency towards 
lower intake rates during the small meals of FAS $+\mathrm{A}$ in the present study does not totally exclude negative effects of biogenic amines on palatability.

In agreement with the findings of Van Os et al. (1995a), no further influence of the added NPN-components were observed on either rumination behaviour or chewing efficiency.

\section{Rumen fill and characteristics}

Of the rumen fluid variables measured only the concentration of $\mathrm{NH}_{3}$ was affected by diet, with the highest concentration observed with FAS $+\mathrm{C}$ during the first hour after the principal meal. In other studies using sheep (Benahmed \& Dulphy, 1987) and dairy cows (Choung et al. 1990) no intake depressions have been observed even with $\mathrm{NH}_{3}$ concentrations in the rumen reaching peak values of $450 \mathrm{mg} / \mathrm{l}$.

The decrease after peaking was observed to be slightly larger with FAS $+C$. This might indicate an increased rate of microbial synthesis as a result of the better $\mathrm{N}$ :digestible organic matter ratio in FAS + C (Russell \& Hespell, 1981). With this dietary treatment a higher flow of microbial or dietary protein to the lower intestines can be expected with may enhance DMI of FAS + C (Charmley \& Veira, 1990). On the other hand, the $\mathrm{NH}_{3}$ concentration in the rumen on FAS appeared not to be limiting for microbial synthesis (Russell \& Hespell, 1981). Therefore, the faster decrease of rumen $\mathrm{NH}_{3}$ concentration could also be the result of increased rates of absorption across the rumen wall (Morris \& Payne, 1970).

Rumen $\mathrm{pH}$ and osmolality followed the patterns which are normally observed after silage feeding (Van Os et al. 1995a). The post-feeding increase of fermentation metabolites in the rumen increased osmolality and decreased $\mathrm{pH}$, both inducing signals of satiation at the ruminal level (Phillip et al. 1981). Similarity of the patterns of both variables for all diets may indicate that biogenic amines, either alone or in combination with $\mathrm{NH}_{3}$ and GABA, did not alter concentrations of metabolites in the rumen to such an extent that they could depress DMI.

The suggested higher rumen liquid volume as a consequence of amine addition (Van Os et al. 1995a) was not observed in the present study. Neither amines nor the combination of NPN-components affected total rumen pool size, the liquid content or the factors measured that might have influenced rumen liquid balance. Biogenic amines did not affect the rate of salivation at intake, which was found to be stimulated by tyramine in rats (Okina et al. 1993). Rumen fluid turnover rate seemed to be higher for FAS + C, but this was merely the result of a higher DMI (Warner \& Stacy, 1968) rather than the effect of the supplemental $\mathrm{N}$-components. The rumen fluid turnover thus remained unaffected by dietary treatment itself, when fluid turnover rate was expressed relative to DMI. The traces of biogenic amines in the rumen are not expected to interfere directly in chemostatic regulation of intake. Physiological effects of amines on intake are possible when significant concentrations are present in the circulation (Joosten, 1988). The highly physiologically active histamine appears not to be absorbed from the rumen (Kay \& Sjaastad, 1974). So, assuming no absorption from the rumen of other types of amines, the ingested amines can only enter the circulation after passing the rumen and being absorbed in the lower intestines. A higher amine passage could be expected with the higher liquid passage with FAS $+C$, but the higher DMI of this silage indicated that the amount of amines that eventually passed the rumen was too low to have negative influences on intake via this route. The rapid degradation in the rumen of the ingested biogenic amines (Van Os et al. $1995 \mathrm{~b}$ ), however, will largely prevent this amine passage. Additionally, Van Os et al. $(1995 b)$ found that the degradation rate increased when the animals were adapted to diets with a high biogenic amine content. This possibly explains the controversial findings of Buchanan-Smith \& Phillip (1986) who observed reduced intake after infusion of biogenic amines into the rumen. In their study the experimental sheep were fed on a high-DM 
lucerne (Medicago sativa) silage in which biogenic amine content was probably low (Voss, 1967). The rumen microflora in those sheep may not have been able to degrade the infused amines rapidly, resulting in an increase of the amount that passed the rumen.

However, it must be considered that the high NPN fraction in poorly preserved silages could be an indirect cause of the lower intake. With this type of silage, when rumen $\mathrm{NH}_{3}$ content is high and is combined with a relatively low energy supply to the rumen microorganisms or to metabolic processes, subclinical $\mathrm{NH}_{3}$ poisoning may be a cause of lower intake (Chamberlain \& Choung, 1993).

In conclusion, it can be stated that neither biogenic amines nor the combination of the major NPN compounds present in poor quality silages affected DMI of the formic acid treated silage to which they were added. In the sheep adapted to the experimental diets, no direct effects of $\mathrm{NH}_{3}$, biogenic amines and GABA were found on variables that indicate interference with chemostatic intake control. However, a minor effect of biogenic amines on palatability cannot be excluded.

This work is part of the PhD project of MVO of the Wageningen Agricultural University, The Netherlands (Department of Human and Animal Physiology), supported by the French Institute National de la Recherche Agronomique (INRA) and the Dutch Dienst Landbouwkundig Onderzoek (DLO). It is a part of a cooperative research project with the DLO-Institute for Animal Science and Health (ID-DLO) Lelystad, The Netherlands. The authors are grateful to Mrs B. Lassalas and $\mathrm{Mr} \mathrm{M}$. Breuer for analytical assistance, to $\mathrm{Mr}$ J. M. Ballet and Mr L. L'Hotelier and his staff for animal care and to Mr S. F. Spoelstra and $\mathrm{Mr}$ A. M. van Vuuren for their valuable advice.

\section{REFERENCES}

Andrieu, J., Demarquilly, C. \& Sauvant, D. (1989). Tables of feed used in France. In Ruminant Nutrition, Recommended Allowances and Feed Tables, pp. 213-303 [R. Jarrige, editor]. London: John Libbey Eurotext.

Baile, C. A. \& Della-Fera, M. A. (1988). Physiology of control of food intake and regulation of energy balance in dairy cows. In Nutrition and Lactation in the Dairy Cow, pp. 251-261 [P. C. Garnsworthy, editor]. London: Butterworths.

Benahmed, H. \& Dulphy, J. P. (1987). Influence de la complémentation des foins traités à l'ammoniac sur leur valeur nutritive (Supplementation of ammonia treated hay: effect on the nutritive value). Annales de Zootechnie 36, 153-170.

Binnerts, W. T., Van't Klooster, A. Th. \& Frens, A. M. (1968). Soluble chromium indicator measured by atomic absorption in digestion experiments. Veterinary Record 82, 470.

Buchanan-Smith, J. G. (1982). Voluntary intake in ruminants affected by silage extracts and amines in particular. In Forage Protein in Ruminant Animal Production, Occasional Publication of the British Society of Animal Production no. 6, pp. 180-182 [D. J. Thomson, D. E. Beever and R. G. Gunn, editors]. Thames Ditton: BSAP.

Buchanan-Smith, J. G. \& Phillip, L. E. (1986). Food intake in sheep following intraruminal infusions of extracts from lucerne silage, with particular reference to organic acids and products of protein degradation. Journal of Agricultural Science, Cambridge 106, 611-617.

Chamberlain, D. G. \& Choung, J. J. (1993). The nutritional value of grass silage. In Proceedings of the 10th International Conference on Silage Research, pp. 131-136 [P. O'Kiely, M. O'Connell and J. Murphy, editors]. Dublin: Dublin City University.

Charmley, E. \& Veira, D. M. (1990). Inhibition of proteolysis in alfalfa silages using heat at harvest: effects of digestion in the rumen, voluntary intake and animal performance. Journal of Animal Science 68, $2042 \% 2051$.

Chiofalo, V., Dulphy, J. P. \& Baumont, R. (1992). Influence on the method of forage conservation on feeding behaviour, intake and characteristics of reticulo rumen content in sheep fed ad libitum. Reproduction Nutrition Development 32, 377-392.

Choung, J. J., Chamberlain, D. G., Thomas, P. C. \& Bradbury, I. (1990). The effects of intraruminal infusions of urea on the voluntary intake and milk production of cows receiving grass silage diets. Journal of Dairy Research 57, 455-464.

Church, D. C. (1976). Digestive Physiology and Nutrition of Ruminants, vol. 1, Digestive Physiology, 2 nd ed. Corvallis, OR: O\&B Books.

Dulphy, J. P. \& Demarquilly, C. (1981). Problèmes particuliers aux ensilages (Particular problems with silages). In Prévision de la Valeur Nutritive des Aliments des Ruminants, pp. 81-104. Versailles: INRA Publications. 
Dulphy, J. P., Demarquilly, C. \& Henry, M. (1975). Perte de composé volatils lors de la détermination à l'étuve en matière seche des ensilages (Determination of silage dry matter content after oven drying and losses of volatile components). Annales de Zootechnie 24, 743-756.

Dulphy, J. P., Michalet-Doreau, B. \& Demarquilly, C. (1984). Etude comparée des quantités ingérées et du comportement alimentaire et mérycique d'ovins et de bovins recevant des ensilages d'herbe réalisés selon des differentes techniques (Comparative study of feed intake, feeding and ruminating behaviour in sheep and cattle subjected to different treatments). Annales de Zootechnie 33, 291-320.

Gill, M., Thiago, L. R. L. \& Buchanan-Smith, J. G. (1987). Intake problems associated with ensiled forages. In Feed Intake by Beef Cattle, Miscellaneous Publication no. 121, pp. 341-352. Stillwater, OK: Oklahoma State University.

Heron, S. J. E., Edwards, R. A. \& McDonald, P. (1986). Changes in the nitrogen components of gammairradiated and inoculated ensiled ryegrass. Journal of the Science of Food and Agriculture 37, 979-985.

Joosten, H. M. L. J. (1988). The biogenic amine contents of Dutch cheese and their toxicological significance. Netherlands Milk and Dairy Journal 42, 25-42.

Kay, R. N. B. \& Sjaastad, Ø. V. (1974). Absorption and catabolism of histamine in sheep. Journal of Physiology 243, 79-99.

McDonald, P., Henderson, A. R. \& Heron, S. J. E. (1991). The Biochemistry of Silage, 2nd ed. Aberystwyth: Cambrian Printers Ltd.

Miettinen, H., Setälä, J. \& Moisio, T. (1991). Estimation of the effect of silage quality on silage palatability and silage intake in dairy cows. In Forage Conservation Towards 2000, pp. 408-409 [G. Pahlow and H. Honig, editors]. Braunschweig-Völkenrode: Institute of Grassland and Forage Research.

Morgan, D. J. \& L'Estrange, J. L. (1976). Effect of dietary additions of hydrochloric and lactic acid on feed intake and metabolism of sheep and cattle. Irish Journal of Agricultural Research 15, 55-63.

Morris, J. G. \& Payne, E. (1970). Ammonia and urea toxicosis in sheep and their relation to dietary nitrogen intake. Journal of Agricultural Science, Cambridge 74, 259-271.

Ohshima, M., McDonald, P. \& Acamovic, T. (1979). Changes during ensilage in the nitrogenous components of fresh and additive treated ryegrass and lucerne. Journal of the Science of Food and Agriculture 30, 97-106.

Okina, A., Hidaka, S., Tashiro, M. \& Abe, K. (1993). The effects of tyramine on salivary flow rate and protein secretion by rat submandibular glands. Journal of Dental Research 72, 879-906.

Russell, J. B. \& Hespell, R. B. (1981). Microbial rumen fermentation. Journal of Dairy Science 64, $1153-1169$.

Phillip, L. E., Buchanan-Smith, J. G. \& Grovum, W. L. (1981). Food intake and ruminal osmolality in sheep: differentiation of the effect of osmolality from that of the products of maize silage fermentation. Journal of Agricultural Science, Cambridge 96, 439-445.

SAS Institute Inc. (1987). SAS/STAT, Guide for Personal Computers, version 6. Cary, NC: SAS Institute Inc.

Seoane, J. R., Dumont, F., Girard, C. L., Bédard, L. \& Matte, J. J. (1984). Effects of intraventricular injections of gamma-aminobutyric acid and related substances on feeding behaviour in satiated sheep. Canadian Journal of Physiology and Pharmacology 62, 1296-1299.

Thiago, L. R. L., Gill, M. \& Dhanoa, M. S. (1992). Studies of the method of conserving grass herbage and frequency of feeding in cattle. 1. Voluntary feed intake, digestion and rate of passage. British Journal of Nutrition 67, 305-318.

Tveit, B., Lingaas, F., Svendsen, M. \& Sjaastad, Ø. V. (1992). Etiology of acetonemia in Norwegian cattle. 1. Effect of ketogenic silage, season, energy level and genetic factors. Journal of Dairy Science 75, $2421-2432$.

Van Os, M., Dulphy, J. P. \& Beaumont, R. (1995a). The effect of protein degradation products in grass silages on feed intake and intake behaviour in sheep. British Journal of Nutrition 73, 51-64.

Van Os, M., Lassalas, B., Toillon, S. \& Jouany, J. P. (1995b). In vitro degradation of amines by mixed rumen microorganisms. Journal of Agricultural Science, Cambridge 125, 299-305.

Voss, N. (1967). Untersuchungen über den Proteinabbau in Grass- und Luzernesilage (Studies of protein degradation in grass and lucerne silage). Das Wirtschaftseigene Futter 13, 130-145.

Warner, A. C. I. \& Stacy, B. D. (1968). The fate of water in the rumen. 2. Water balances throughout the feeding cycle in sheep. British Journal of Nutrition 22, 389-410.

Wilkins, R. J., Hutchinson, K. J., Wilson, R. F. \& Harris, C. E. (1971). The voluntary intake of silage by sheep. 1. Interrelationships between silage composition and intake. Journal of Agricultural Science, Cambridge 77 , $531-537$. 